\title{
PENGARUH INTELLECTUAL CAPITAL TERHADAP KINERJA PASAR (Pada Perusahaan Sektor Property dan Real Estate yang Terdaftar di Bei Tahun 2014-2018)
}

\author{
Nurul Azizah( ${ }^{1}$, \\ Institut Teknologi dan Bisnis Ahmad Dahlan Jakarta \\ nurulazizah0307@gmail.com ${ }^{1}$ \\ Iwan Setiadi ${ }^{(2)}$ \\ Institut Teknologi dan Bisnis Ahmad Dahlan Jakarta
}

\begin{abstract}
The purpose of this research is to know the effect of Intellectual Capital on market performance partially and together at Property and Real Estate company listed on the Indonesia Stock Exchange (IDX).

The population in this study is the Property and Real Estate sector companies that are listed on the Indonesia Stock Exchange in 2014-2018. With a total sample of 39 companies taken by purposive sampling. The research variable consists of dependent variables is market performance and independent variables is intellectual capital which is proxied with human capital efficiency, structural capital efficiency and capital employed efficiency. The research method used is descriptive statistical method. The analysis used is multiple linear regression analysis to determine the intellectual capital equation both simultaneously and partially to market performance helping by IBM SPSS Statistics 20.

The results of this study indicate that human capital efficiency and structural capital efficiency does not affect market performance, while capital employed efficiency has a positive effect on market performance.
\end{abstract}

Keywords: Human Capital Efficiency, Structural Capital Efficiency, Capital Employed Efficiency, Market Performance.

\section{PENDAHULUAN}

Menurut Holland (2002) dalam

Devi, Budiasih dan Badera (2017) keputusan investasi yang hanya berfokus pada informasi finansial yang terdapat pada laporan keuangan tidak akan menjamin bahwa keputusan investasi yang dilakukan telah tepat. Fenomena yang menyebabkan bangkrutnya perusahaan Enron dan Worldcom telah memberikan bukti bahwa perusahaan yang selalu menyajikan informasi finansial dalam bentuk laporan keuangan yang sangat baik belum menjamin kesinambungan usaha perusahaan tersebut. Informasi yang hanya bersifat 
finansial tidak cukup dijadikan sebagai dasar dalam menilai suatu perusahaan (Holland 2002). Menurut Anisa (2012) dalam Devi, Budiasih dan Badera (2017) pengungkapan informasi nonfinansial juga dinilai penting dalam pertimbangan keputusan investasi.

Persaingan perusahaan bisnis telah berkembang pesat seiring kemajuan ilmu pengetahuan dan teknologi dalam dekade terakhir ini. Berbagai peluang dan tantangan bisnis yang ada berusaha dimanfaatkan dan dihadapi agar dapat bersaing dengan para kompetitor. Hal ini mendorong para pelaku bisnis untuk menggunakan dan memanfaatkan sumber daya yang dimilikinya secara efektif dan efisien dalam mencapai tujuannya. Salah satu tujuan pelaku bisnis saat ini adalah meningkatkan kinerja pasar suatu perusahaan agar dapat menarik para investor dalam menanamkan modal nya pada perusahaan tersebut. Keberhasilan perusahaan dalam meningkatkan kinerja pasar perusahaan dan menghadapi persaingan bisnis dapat dilihat dari sejauh mana perusahaan meningkatkan nilai saham perusahaan yang telah diperdagangkan di pasar modal.

Di Indonesia, fenomena intellectual capital (IC) berkembang setelah muncul PSAK No. 19 (revisi 2000) tentang aktiva tidak berwujud. Menurut PSAK No. 19, aktiva tidak berwujud adalah aktiva nonmoneter yang dapat diidentifikasi dan tidak mempunyai wujud fisik serta dimiliki untuk digunakan dalam menghasilkan atau menyerahkan barang atau jasa, disewakan kepada 2 pihak lainnya, atau untuk tujuan administratif (Ikatan Akuntan Indonesia, 2007). Meskipun tidak dinyatakan secara eksplisit sebagai intellectual capital (IC), namun lebih kurang intellectual capital (IC) telah mendapat perhatian. Banyak perusahaan yang mulai memperhatikan aktiva tidak berwujud sebagai strategi bisnisnya untuk mencapai keunggulan kompetitif. Hal ini yang menyebabkan perusahaan menerapkan knowledge based business.

Menurut Sawarjuwono dan Kadir (2003), dengan semakin berkembangnya perekonomian dunia yang ditandai oleh kemajuan dibidang teknologi informasi, persaingan ketat, dan pertumbuhan inovasi yang terus menerus. Dalam hal ini perusahaan mampu mempertahankan bisnisnya didasarkan pada tenaga kerja (labour - based business) menuju knowledge based business (bisnis berdasarkan pengetahuan), dengan mengutamakan ilmu pengetahuan sehingga ekonomi yang berbasis ilmu pengetahuan dengan menerapan manajemen pengetahuan (knowledge management) maka kemakmuran suatu perusahaan akan bergantung pada suatu penciptaan transformasi dan kapitalisasi dari pengetahuan itu sendiri. Menurut Hurwitz, et al. (2012) telah terjadi peningkatan yang besar pada knowledge workers dan aset tak berwujud pada dekade akhir ini. Hal ini disebabkan oleh adanya alasan utama yang dikaitkan dengan keberhasilan perusahaan, seperti over valuation yang besar pada perusahaan teknologi tinggi, adalah dengan meningkatkan pengetahuan. 
Pulic (1998) dalam Ulum (2017:119) memperkenalkan pengukuran intellectual capital dengan menggunakan "Value Added Intellectual Coefficient" (VAICTM). Metode VAICTM dirancang untuk menyediakan informasi mengenai efisiensi penciptaan nilai (value creation) dari aset berwujud dan tidak berwujud yang dimiliki oleh perusahaan.Komponen utama dari VAICTM dalam penelitian ini adalah Capital Employed Efficiency (CEE), Human Capital Efficiency (HCE), dan Structural Capital Efficiency (SCE).

Peranan Manajemen Sumber Daya Manusia (SMDM) saat ini jauh berbeda dengan peranannya sepuluh tahun yang lalu. Dalam lingkungan yang kompleks, dinamis, turbulen dan sangat kompetitif dituntut pengelolaan SDM yang efektif dan efisien. Beberapa upaya untuk mengukur dan melaporkan nilai SDM dalam laporan keuangan semakin banyak. Menurut satu perkiraan, sampai 75 persen sumber nilai dalam suatu organisasi adalah intangible intellectual capital, yaitu kreativitas, produktivitas dan pelayanan yang memberikan karyawan. MSDM yang efektif merupakan kunci meningkatkan nilai intellectual capital. Pada saat ini lebih banyak organisasi tertarik pada pengembangan intellectual capital untuk mendapatkan keunggulan bersaing atas kompetitornya. Akibatnya, organisasi berusaha menarik, mengembangkan dan mempertahankan knowledge worker. Knowledge worker adalah karyawan yang memberikan kontribusi kepada organisasi bukan dengan tenaga kasar, melainkan dengan apa mereka ketahui atau pengetahuan khususnya. (Kaswan 2012:6-13).

\section{KAJIAN PUSTAKA DAN PENGEMBANGAN HIPOTESIS}

\section{Stakeholder Theory}

Istilah stakeholder dalam definisi klasik (yang paling sering dikutip) adalah definisi Freeman dan Reed (1983), dalam Ulum (2009) yang menyatakan bahwa stakeholder adalah: "any identifiable group or individual who can affect the achievement of an organisation's objectives, or is affected by the achievement of an organisation's objectives".

Jelas sekali bahwa beberapa teori , seperti keagenan, ataupun beberapa ideology, seperti kapitalisme dan sosialisme, sangat dipengaruhi oleh pardigma managerial capitalism tersebut. Hal itu terlihat jelas dari peran sentral pemilik (shareholders) dan manajemen dalam menjelaskan fenomena bisnis dan ekonomi dimasyarakat. hal ini berbeda dengan konsep dalam teori pemangku kepentingan (Stakeholder theory) yang memandang bahwa kelangsungan perusahaan didalam lingkungan bisnisnya tergantung pada berbagai pihak pemangku kepentingan, yang tidak hanya terbatas pada pemilik dan manajemen, seperti misalnya pemerintah, karyawan, kreditur, dan konsumen. Institusi tercipta hanya untuk memenuhi kepentingannya sendiri melainkan memenuhi kebutuhan maca-macam pihak yang ada disekitarnya. Teori Pemangku Kepentingan paling tidak memiliki tiga 
pendekatan yang saling terkait yaitu deskriptif, instrumental, dan normatif.

Tujuan utama dari teori stakeholder adalah untuk membantu manajer korporasi mengerti lingkungan stakeholder mereka dan melakukan pengelolaan dengan lebih efektif di antara keberadaan hubungan-hubungan di lingkungan perusahaan mereka. Namun demikian, tujuan yang lebih luas dari teori stakeholder adalah untuk menolong manajer korporasi dalam meningkatkan nilai dari dampak aktifitas-aktifitas mereka, dan meminimalkan kerugiankerugian bagi stakeholder.Pada kenyataannya, inti keseluruhan teori stakeholder terletak pada apa yang akan terjadi ketika korporasi dan stakeholder menjalankan hubungan mereka.

Dalam konteks untuk menjelaskan tentang konsep IC (Intellectual Capital), teori stakeholder harus dipandang dari kedua bidangnya, baik bidang etika (moral) maupun bidang manajerial. Bidang etika berargumen bahwa seluruh stakeholder memiliki hak untuk diperlakukan secara adil oleh organisasi, dan manajer harus mengelola organisasi untuk keuntungan seluruh stakeholder. Ketika manajer mampu mengelola organisasi secara maksimal, khususnya dalam upaya penciptaan nilai bagi perusahaan, maka itu artinya manajer telah memenuhi aspek etika dalam teori ini. Penciptaan nilai (value creation) dalam konteks ini adalah dengan memanfaatkan seluruh potensi yang dimiliki perusahaan baik karyawan (human capital), aset fisik (physical capital), maupun structural capital. pengelolaan yang baik atas seluruh potensi ini akan menciptakan value added bagi perusahaan yang kemudian dapat mendorong kinerja keuangan perusahaan untuk kepentingan stakeholder.

\section{Pengembangan Hipotesis}

a. Pengaruh Human Capital Efficiency (HCE) terhadap Kinerja Pasar (MBV)

Nurhayati (2017) menyatakan bahwa human capital merupakan modal yang terkait dengan pengembangan sumber daya manusia perusahaan, seperti kompetensi, komitmen, motivasi, dan loyalitas karyawan. Human capital menunjukkan kemampuan perusahaan dalam mengelola sumber daya manusia. Keunggulan kompetitif yang dihasilkan karyawan memiliki nilai yang tidak dapat ditiru oleh perusahaan lainnya, diharapkan mampu mendukung kemampuan perusahaan dalam memenuhi kebutuhan pelanggan, sehingga perusahaan memiliki kesempatan untuk dapat meningkatkan pendapatan yang berdampak pada kinerja perusahaan. Meningkatnya kinerja perusahaan berdampak secara langsung pada persepsi pasar terhadap perusahaan, hal ini mengakibatkan value perusahaan semakin meningkat. Sehingga, dengan nilai perusahaan yang meningkat maka kinerja pasar pun semakin meningkat.

H1 : Human Capital Efficiency berpengaruh positif terhadap kinerja pasar.

b. Pengaruh Structural Capital Efficiency (SCE) terhadap Kinerja Pasar (MBV) 
Structural Capital Efficiency yaitu hal yang dilakukan oleh perusahaan dengan menekankan pada kemampuan perusahaan dan strukturnya yang mendukung usaha karyawan untuk menghasilkan kinerja intelektual yang optimal serta kinerja bisnis secara keseluruhan, misalnya sistem operasional perusahaan, proses manufacturing, budaya organisasi, filosofi manajemen dan semua bentuk intellectual property yang dimiliki perusahaan (Sawarjuwono dan Kadir, 2003). Pengelolaan modal struktural perusahaan yang baik akan menghasilkan keunggulan kompetitif yang berharga dan langka, sehingga diyakini bahwa perusahaan mampu bersaing dan bertahan di lingkungan bisnis yang dinamis. Dengan memiliki keunggulan kompetitif maka kinerja perusahaan akan meningkat, hal ini akan berdampak langsung pada persepsi pasar terhadap nilai perusahaan akan meningkat. Sehingga, nilai perusahaan meningkat maka rasio market to book value pun semakin meningkat.

\section{H2 : Structural Capital Efficiency berpengaruh positif terhadap kinerja pasar.}

\section{c. Pengaruh Capital Employeed Efficiency (CEE) terhadap Kinerja Pasar (MBV)}

Relational capital atau capital employeed efficiency dapat muncul dari berbagai bagian diluar lingkungan perusahaan yang dapat menambah nilai bagi perusahaan tersebut. Capital employeed efficiency yang dikelola oleh perusahaan mampu menciptakan keunggulan kompetitif, dengan mengkombinasikan modal (fisik dan keuangan) karyawan (CE) (Pulic, 1998). Kombinasi modal yang dikelola perusahaan akan mempengaruhi kinerja perusahaan, dengan menggunakan modal yang minimal maka akan menghasilkan penjualan yang meningkat atau dengan modal yang digunakan maksimal maka akan menghasilkan penjualan yang semakin meningkat. Sawarjuwono dan kadir (2003) dalam Dwipayani (2014) Peningkatan yang terjadi pada penjualan dikarenakan hubungan yang harmonis / association network yang dimiliki oleh perusahaan dengan para mitranya, baik yang berasal dari para pemasok yang andal dan berkualitas, berasal dari pelanggan yang loyal dan merasa puas akan pelayanan perusahaan yang bersangkutan, berasal dari hubungan perusahaan dengan pemerintah maupun dengan masyarakat sekitar. Sehingga, hubungan sosial perusahaan secara internal dan eksternal yang dikelola dengan baik akan menghasilkan keunggulan kompetitif tersendiri bagi perusahaan sehingga dapat meningkatkan kinerja perusahaan menjadi semakin baik. Meningkatnya kinerja perusahaan secara langsung akan berdampak pada persepsi pasar. Persepsi pasar inilah yang akan meningkatkan nilai pasar perusahaan, maka market to book value akan meningkat juga.

H3 : Capital employeed Efficiency berpengaruh positif terhadap kinerja pasar. 


\section{METODE PENELITIAN}

\section{Populasi dan Sampel}

Populasi dalam penelitian ini adalah perusahaan properti dan real estate yang terdaftar di Bursa Efek Indonesia dalam periode 2014-2018. Jumlah populasi dalam penelitian ini adalah 58 perusahaan Property dan Real Estate. Pengambilan sampel yang dilakukan dengan metode purposive sampling. Menurut Sugiyono (2018:85) bahwa purposive sampling adalah teknik pengambilan sampel sumber data dengan pertimbangan tertentu. Alasan menggunakan teknik purposive sampling adalah karena tidak semua sampel memiliki kriteria yang sesuai dengan fenomena yang diteliti. Perusahaan Property dan Real Estate yang telah memenuhi kriteria sebagai sampel penelitian sebanyak 39 perusahaan selama 5 tahun penelitian, dan 1 data terkena outlier sehingga jumlah data yang digunakan pada penelitian ini sebanyak 194 data observasi.

\section{Definisi dan Pengukuran Variabel \\ a. Variabel Independen}

Dalam penelitian ini terdapat 3 (tiga) variabel independen (bebas), yaitu Human Capital Efficiency (HCE), Structural Capital Efficiency (SCE), dan Capital Employed Efficiency (CEE).

Dalam Ulum (2017:124) Tahapan perhitungan Intellectual Capital di proksikan dengan Human Capital Efficiency (HCE), Structural Capital Efficiency (SCE), dan Capital Employed Efficiency (CEE) yang diukur yaitu dengan Value Added Intellectual Capital (VAICTM) adalah sebagai berikut:

1. Menghitung Value Added (VA) VA= OUT - IN

Dimana:

VA : Value Added (output input)

OUT : Total Pendapatan

IN : Beban usaha kecuali beban gaji dan tunjangan karyawan

2. Menghitung Human Capital Efficiency (HCE)

$\mathrm{HCE}=\mathrm{VA} / \mathrm{HC}$

Dimana :

VA : Selisih antara out dan in

$\mathrm{HC}$ : Beban karyawan

3. Menghitung Structural Capital Efficiency (SCE) SCE $=$ SC $($ VA-HC) / VA

Dimana :

VA : Selisih antara out dan in HC : Beban karyawan

4. Menghitung Capital Employeed Efficiency (CEE)

$\mathrm{CEE}=\mathrm{VA} / \mathrm{CE}$

Dimana :

VA : Selisih antara out dan in

CE : Nilai buku

\section{b. Variabel Dependen}

Variabel dependen yang digunakan dalam penelitian ini adalah Kinerja Pasar

Market performance adalah efisiensi dari suatu pasar dalam menggunakan sumber daya yang langka untuk 
memenuhi permintaan konsumen akan barang dan jasa, yaitu seberapa baik suatu pasar telah memberikan konstribusi pada optimasi kesejahteraan ekonomi. Market performance merujuk pada penilaian kinerja perusahaan oleh pasar yang tercermin dari nilai sebuah perusahaan berdasarkan perhitungan Market to book value (MBV).

Kinerja pasar dapat dirumuskan sebagai berikut sesuai penelitian Dwipayani (2014) dan dalam (Kodrat dan Indonanjaya, 2010:241) :

MBV = Harga saham X Jumlah saham biasa yang beredar / nilai buku aset bersih

\section{Teknik Analisis Data}

Model analisis yang digunakan dalam penelitian ini adalah model analisis regresi linier berganda. Analisis linier berganda dimaksudkan untuk menguji sejauh mana dan bagaimana arah variabel-variabel indepen berpengaruh terhadap variabel dependen. Teknik analisis dalam penelitian ini diolah dengan menggunakan program SPSS versi 20 for Windows. Analisis yang digunakan untuk menguji persamaan tersebut secara matematis dirumuskan sebagai berikut :

$\mathrm{MBV}=\mathrm{a}+\beta_{1} \mathrm{HCE}+\beta_{2} \mathrm{SCE}+\beta_{3} \mathrm{CEE}+\varepsilon$

Keterangan :

$\begin{aligned} \mathrm{MBV}= & \text { Kinerja Pasar } \\ \mathrm{a}= & \text { Konstanta } \\ \mathrm{HCE}= & \text { Human Capital Efficiency } \\ \mathrm{SCE}= & \text { Structural Capital } \\ & \text { Efficiency }\end{aligned}$

$$
\begin{aligned}
\mathrm{CEE}= & \text { Capital Employeed } \\
& \text { Efficiency } \\
ß 1 ß 2 ß 3= & \text { Koefisien Regresi } \\
\varepsilon \quad= & \text { Error }
\end{aligned}
$$

\section{HASIL DAN PEMBAHASAN}

\section{Analisis Statistik Deskriptif}

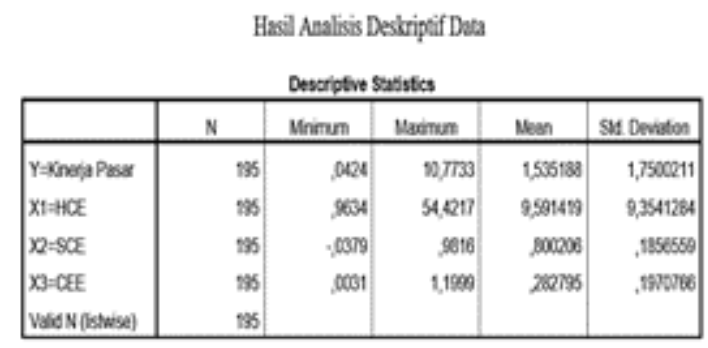

Sumber : Output SPSS 20

dapat dijelaskan sebagai berikut:

a. Mean adalah nilai rata-rata suatu kelompok data atau teknik penjelasan kelompok yang didasarkan atas nilai rata-rata dari kelompok tersebut. Mean terbesar dihasilkan oleh Human Capital Efficiency (HCE) sebesar 9,591419, sementara mean terkecil diperoleh oleh variabel Capital Employeed Efficiency (CEE) sebesar 0,282795 . Sementara itu mean dari variabel lainnya yaitu Structural Capital Efficiency (SCE) sebesar 0,800206, dan Kinerja Pasar sebesar 1,535188 .

b. Maximum adalah nilai terbesar dalam sebuah kelompok data. Maximum terbesar dihasilkan oleh Human Capital Efficiency (HCE) sebesar 54,4217, sementara maximum terkecil diperoleh oleh Structural Capital Efficiency (SCE) sebesar 0,9816. Sementara itu maximum variabel lainnya yaitu Capital Employeed 
Efficiency (CEE) sebesar 1,1999 dan Kinerja Pasar sebesar 10,7733.

c. Minimum adalah nilai terkecil dalam sebuah kelompok data. Minimum terbesar dihasilkan oleh Human Capital Efficiency (HCE) sebesar 0,9634, sementara minimum terkecil diperoleh oleh variabel Structural Capital Efficiency (SCE) sebesar 0,0379. Sementara itu minimum variabel lainnya yaitu Employeed Efficiency (CEE) sebesar 0,0031 dan Kinerja Pasar sebesar 0,0424.

d. Standar deviasi adalah ukuran dispersi atau penyebaran data. Nilai standar deviasi terbesar dialami oleh variabel Human Capital Efficiency (HCE) yaitu sebesar 9,3541284 yang berarti bahwa variabel Human Capital Efficiency (HCE) memiliki tingkat risiko yang lebih tinggi dibandingkan dengan variabel-variabel yang lain. Sementara variabel Structural Capital Efficiency (SCE) mempunyai tingkat resiko yang paling rendah, yaitu sebesar 0,1856559. Hal ini menunjukkan bahwa Structural Capital Efficiency (SCE) selama periode penelitian mengalami perubahan yang tidak terlalu fluktuatif.

\section{Uji Asumsi Klasik}

a. Uji Normalitas

Menurut Ghozali (2018) data penelitian dikatakan menyebar normal atau memenuhi uji normalitas apabila nilai Asymp.Sig (2-tailed) variabel residual berada diatas 0,05 . Sebaliknya, apabila nilai Asymp.Sig (2-tailed) variabel residual berada dibawah 0,05, maka data tersebut diatas tidak berdistribusi normal atau tidak memenuhi uji normalitas.

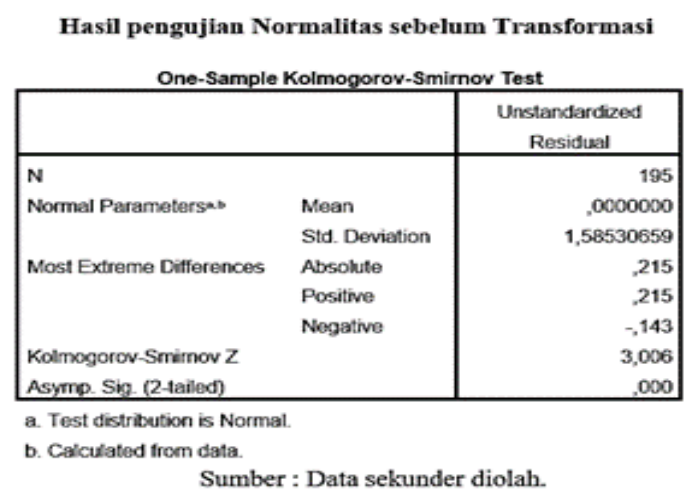

Hasil uji normalitas diatas menunjukan bahwa data tidak terdistribusi normal karena probability value $<0,05$ sehingga harus ditransformasi agar data terdistribusi secara normal. Perlakuan terhadap data yang tidak normal adalah dengan melakukan transformasi atau mengubah data ke dalam bentuk Ln (logaritma natural) untuk memperkecil skala ukuran data dan untuk menormalkan distribusi data. Hasil uji normalitas data setelah transformasi adalah sebagai berikut:

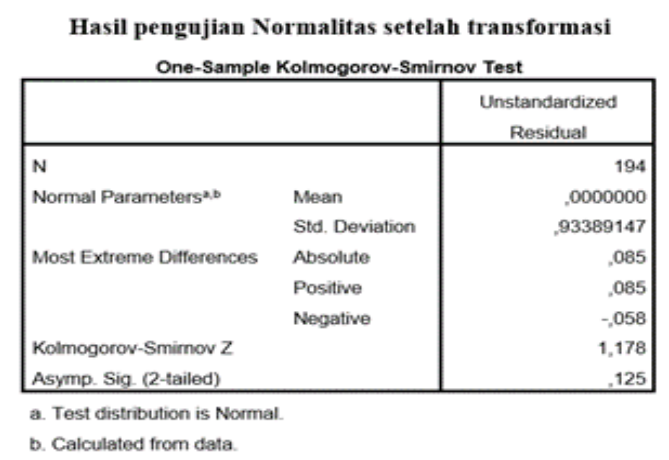

Tabel tersebut menunjukan bahwa nilai Kolmogorov-Smirnov adalah 1,178 dan signifikansi 0,125 , nilai signifikansi tersebut jauh diatas 0,05 yang mengartikan bahwa data residual terdistribusi dengan normal, 
sedangkan grafik normal plot dapat dilihat bahwa data menyebar disekitar garis diagonal dan mengikuti arah garis diagonal. Kesimpulannya adalah data dapat terdistribusi dengan normal dan model regresi dapat dipakai untuk pengujian selanjutnya.

\section{b. Uji Autokorelasi}

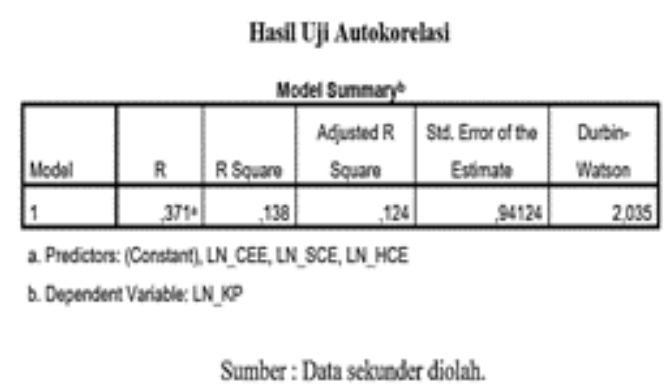

Didapat nilai DW yang di hasilkan dari model regresi adalah 2,035 sedangkan berdasarkan tabel DW dengan signifikansi 0,05 dan jumlah data $(\mathrm{n})=$ 194, serta $\mathrm{k}=3$ ( $\mathrm{k}=$ jumlah variabel independen) diperoleh nilai $\mathrm{dL}$ sebesar 1,7337 dan nilai dU sebesar 1,17965. dengan demikian DW terletak antara dU dan $(4-d U)=1,17965<2,035<2.2035$ maka dapat di simpulkan bahwa kita tidak bisa menolak Ho yang menyatakan bahwa tidak ada autokorelasi positif atau negatif atau dapat disimpulkan tidak terdapat autokorelasi pada data yang diuji.

\section{c. Uji Heteroskedastisitas}

Hasil uji heteroskedastisitas menunjukan bahwa grafik scatterplot antara SRESID dan ZPRED menunjukan pola penyebaran, dimana

Sumber : Output SPSS 20

titik-titik menyebar diatas dan dibawah 0 pada sumbu Y. Hal ini menunjukan bahwa tidak terjadi heteroskedastisitas pada data yang akan digunakan.
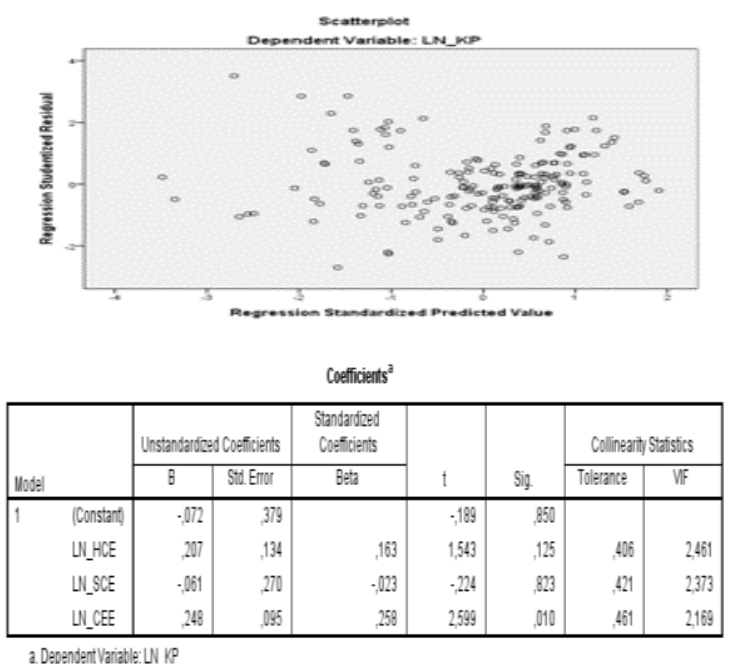

\section{d. Uji Multikolinieritas}

Hasil uji heteroskedastisitas menunjukan bahwa data penelitian sekunder dikatakan bebas dari masalah multikolineritas apabila kolom Colinearity Statistics menujukkan hasil Tolerance > 0,1 dan Nilai Variation Inflasi Factor $(\mathrm{VIF})<10$. Hal ini berarti data penelitian bebas dari masalah multikolinieritas.

\section{Hasil Uji Hipotesis}

\section{a. Uji Adjusted R Square}

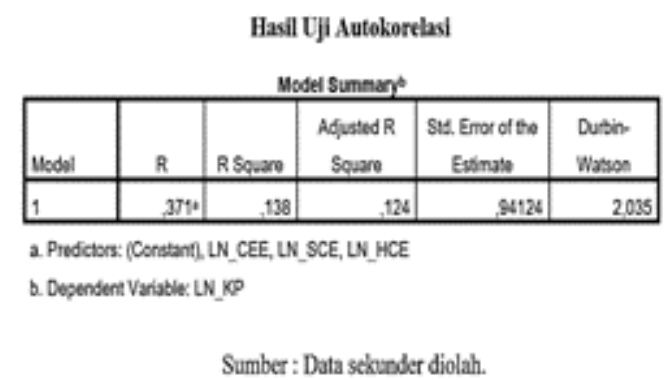

Sumber : Output SPSS 20

Diketahui bahwa nilai Adjusted $\mathrm{R}$ Square sebesar 0.124 hal ini berarti bahwa $12,4 \%$ yang berarti bahwa kemampuan variabel human capital 
efficiency, structural capital efficiency, capital employeed efficiency dalam menjelaskan variabel kinerja pasar adalah sebesar 12,4\%. Sedang sisa sebesar $87,6 \%$ dijelaskan oleh variabel lain diluar dari variabel penelitian ini.

$\mathrm{R}$ sebesar 0,371 atau $37,1 \%$ memiliki arti bahwa korelasi bergandanya adalah sedang. Sedangkan Standard Error of the Estimate (SEE) sebesar 0,35117.

\section{b. Uji Simultan (Uji F)}

\begin{tabular}{|c|c|c|c|c|c|}
\hline Model & $\begin{array}{l}\text { Sum of } \\
\text { Squares }\end{array}$ & Df & $\begin{array}{c}\text { Mean } \\
\text { Square }\end{array}$ & $F$ & Sig. \\
\hline 1 Regression & 26,915 & 3 & 8,972 & 10,127 &, $000^{\circ}$ \\
\hline Residual & 168,326 & 190 & ,886 & & \\
\hline Total & 195.240 & 193 & & & \\
\hline
\end{tabular}

a. Dependent Variable: LN_KP

b. Predictors: (Constant), LN_CEE, LN_SCE, LN_HCE

Berdasarkan uji Anova atau Uji F, probabilitas signifikansi menunjukan 0,000 nilai probabilitas pengujian lebih kecil dari 0,05 yang berarti bahwa secara simultan variabel human capital efficiency, structural capital efficiency, capital employeed efficiency berpengaruh signifikan terhadap variabel kinerja pasar.

\section{c. Uji Parsial (Uji t)}

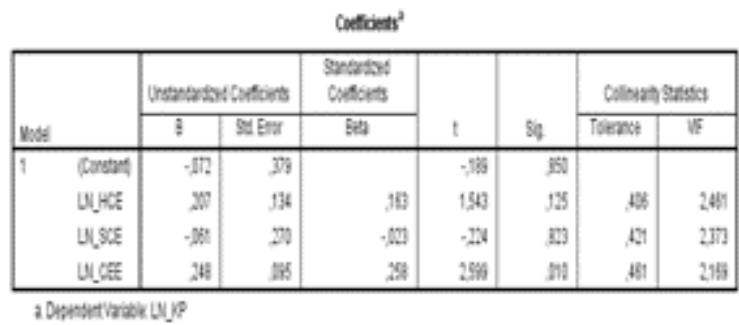

Sumber : Output SPSS 20

Berdasarkan tabel diatas dapat di ketahui bahwa pengujian yang dilakukan untuk memperoleh pengaruh yang signfikan dari ke tiga variabel terhadap kinerja pasar adalah sebagai berikut :

1. Koefisien regresi variabel human capital efficiency sebesar 0,207 yang berarti mempunyai pengaruh positif terhadap kinerja pasar. Nilai signifikansi adalah 0,125 diatas 0,05 menunjukan bahwa variabel human capital efficiency secara parsial tidak berpengaruh terhadap kinerja pasar. Maka dapat disimpulkan bahwa $\mathbf{H}_{\mathbf{1}}$ dalam penelitian ini ditolak.

2. Koefisien regresi variabel structural capital efficiency sebesar -0,061 yang berarti mempunyai pengaruh negatif terhadap kinerja pasar. Nilai signifikansi adalah 0,823 atau probabilitas signifikansinya diatas 0,05 menunjukan bahwa variabel structural capital efficiency secara parsial tidak berpengaruh terhadap kinerja pasar. Maka dapat disimpulkan bahwa $\mathbf{H}_{2}$ dalam penelitian ini ditolak.

3. Koefisien regresi variabel capital employeed efficiency sebesar 0,248. Hal ini menunjukkan bahwa capital employeed efficiency mempunyai pengaruh negatif terhadap kinerja pasar. Nilai signifikansi adalah 0,010 atau probabilitas signifikansinya dibawah 0,05 menunjukkan bahwa variabel capital employeed efficiency secara parsial berpengaruh positif terhadap kinerja pasar. Maka dapat disimpulkan bahwa $\mathbf{H}_{\mathbf{3}}$ dalam penelitian ini diterima. 


\section{Kesimpulan}

Berdasarkan hasil analisis data dan pembahasan yang telah diuraikan, maka kesimpulan dari penelitian ini adalah sebagai berikut:

1. Variabel human capital efficiency (X1) secara parsial tidak berpengaruh terhadap Kinerja Pasar (Y). Hal ini dibuktikan dengan hasil koefisien regresi sebesar 0,207 dan nilai signifikansi adalah 0,125 diatas 0,05.

2. Variabel structural capital efficiency (X2) secara parsial tidak berpengaruh terhadap Kinerja Pasar (Y). Hal ini dibuktikan dengan hasil koefisien regresi sebesar $-0,061$ dan nilai signifikansi adalah 0,823 atau probabilitas signifikansinya diatas 0,05 .

3. Variabel capital employeed efficiency (X3) secara parsial berpengaruh terhadap Kinerja Pasar (Y). Hal ini dibuktikan dengan hasil koefisien regresi sebesar 0,248 dan nilai signifikansi adalah 0,010 atau probabilitas signifikansinya dibawah 0,05 .

\section{Saran}

Penelitian ini memiliki beberapa keterbatasan, antara lain:

1. Periode penelitian relatif masih singkat hanya 5 tahun, yaitu selama periode 2013-2016.

2. Penelitian terbatas hanya pada perusahaan property dan real estate yang terdaftar di Bursa Efek Indonesia.
3. Variabel yang digunakan hanya intellectual capital tanpa menambahkan variabel lain.

\section{Referensi}

Brooking, A. 1996. Intellectual Capital: Core Assets for the Third Millenium, Enterprise Thomson Business Press, London, United Kingdom.

Devi, Budiasih dan Badera, 2017. Pengaruh Pengungkapan Enterprise Risk Management Dan Pengungkapan Intellectual Capital Terhadap Nilai Perusahaan. Jurnal Akuntansi dan Keuangan Indonesia, Juni 2017, Vol. 14, No. 1 , hal $20-45$.

Dwipayani (2014). Pengaruh Intellectual Capital Terhadap Profitabilitas Dan KinerjaPasar (Studi Empiris Pada Perusahaan Perdagangan Dan Jasa). Skripsi Program Sarjana (S1) pada Program Sarjana Fakultas Ekonomika dan Bisnis Universitas Diponegoro.

Freeman, R.E., and reed. 1983. "Stockholder and stakeholders: a new perspective on corporate governance". Californian Management Review. Vol 25. No.2.pp 88-106.

Ghozali, I dan A. Chariri. 2007. Teori Akuntansi, Edisi 3. Semarang: Badan Penerbit. Universitas Diponegoro.

Hurwitz, J. 2012. "The Lingkage between Management Practices, Intangibles Performance and Stock Returns." dalam Journal of Intellectual Capital.

Ikatan Akuntan Indonesia 2007. Standar Akuntansi dan Keuangan. Jakarta: Salemba Empat.

Kaswan (2012). Manajemen sumber daya manusia untuk keunggulan bersaing organisasi, Penerbit Graha Ilmu.

Kodrat dan Indonanjaya, (2010). Manajemen Investasi, Pendekatan Teknikal dan Fundamental untuk Analisis Saham. Penerbit Graha Ilmu. 
Najibullah, Syed. (2005). “An Empirical Investigation of The Relationship Between Intellectual Capital and Firms' Market Value and Financial Performance : in Contet of Commercial Banks of Bangladesh".

Pangestu dan Wijaya, (2014). Pengaruh Intellectual Capital terhadap Market Value dan Kinerja Keuangan. Jurnal Akuntansi dan Investasi Vol.15 No 2, Juli 2014.

PSAK No. 19 (revisi 2000)

Pulic, (1998). "Measuring the performance of intellectual capital potential in knowledge economy". Paper presented at the $2^{\text {nd }} M c$ Master Word Congress on Measuring and Managing Intellectual Capital by the Austrian Team for Intellectual Potential.

Sawarjuwono dan Kadir, 2003, "Intellectual Capital: perlakuan, pengukuran, dan laporan (sebuah library research). Jurnal Akuntansi dan Keuangan. Vol. 5 No.1 PP.35-37.

Sharma, et.al, (2013). Corporate social responsibility and firm performance in the airline industry: the moderating role of oil prices. S. Lee et all/Tourism Management 38 (2013) 20-30.

Siti Nurhayati (2017) Analisa Pengaruh Intellectual Capital Terhadap Kinerja Pasar Dan Kinerja Keuangan Pada Perusahaan LQ45 Yang Terdaftar Di Bursa Efek Indonesia Periode Tahun 2010-2013. Jurnal Aset (Akuntansi Riset) Vol.9 No.1 2017.

Sugiyono. 2018. Metode Penelitian Pendidikan Pendekatan Kuantitatif, Kualitatif, dan $R \& D$. Bandung: Alfabeta.

Stewart, T.A. 1997. Intellectual Capital: The New Wealth of Organizations. Doubleday/Currency, New York, United State of America.

Ulum, Ihyaul. (2017). Intellectual Capital : Model Pengukuran, Framework Pengungkapan dan Kinerja Organisasi, Penerbit Universitas Muhammadiyah Malang, Malang. 